\title{
The Application of Community Service for the State Defense Education in the Sea Lift Command (Kolinlamil), North Jakarta
}

\author{
Ceppi Hilmansyah, Ma'ruf, Suparno Eko Widodo M.M
}

\begin{abstract}
The aims of this study is to explain how the application of community service for the education of defending the country in the Sealift Command North Jakarta. The sub focus of this research are: 1) the organizational structure of Sealift Command North Jakarta, 2) the culture of Sealift Command North Jakarta in providing community services, and the capital found in Sealift Command in providing services to thesociety.
\end{abstract}

This study uses a qualitative approach with a case study method and uses quota samples. The research population was the Indonesian Navy (TNI AL) in Sealift Command North Jakarta who were in charge of providing services to the public in their state defense education. The data obtained based on observations, interviews, questionnaires, and then analyzed by triangulation.

The results of this study indicate that the organizational structure formed was headed by a Commander of Sealift Command. The Commander is assisted by the Sealift Chief of Staff and there are 5 assistants to assist the C.O. The community service is carried out by the Maritime Potential Assistant and the Head of the Information Office who provide information in the form of direction and services to the people who visit Sealift Command North Jakarta.

In order for the services to be delivered well, Kolinlamil adhered to the Navy's Doctrine of Discipline, Honorary and Hierarchy. In addition, Kolinlamil carried out an inventory of his capital in an effort to provide good service to the community were carried out by the Potential Maritime Sealift Commander Assistant (Aspotmar) who is domiciled and is responsible to the C.O of Kolinlamil. In carrying out daily tasks is coordinated by the Sealift Commander (Pangkolinlamil) Chief of Staff.

Index Terms: Community Service, Sealift Command (Kolinlamil), National Defend.

\section{INTRODUCTION}

Indonesia is an archipelagic country, where there are 17,508 islands from large islands to small islands, 1,128 ethnic groups and 748 regional languages (Data from the Central Statistics Agency, 2011). With such fantastic diversity, of course there are various differences in all aspects, ways of thinking, and perspectives. High tolerance and a sense of belonging are the basic keys to be able to

Revised Manuscript Received on September 22, 2019.

Ceppi Hilmansyah, Department of Management (MSDM) Post Graduated Universitas Negeri Jakarta. DKI Jakarta 13220, Indonesia, chillconsult69@gmail.com

Prof.Dr.Ma'ruf, Profesor at Universitas Negeri Jakarta. DKI Jakarta 13220, Indonesia

Dr.Suparno Eko Widodo M.M, Profesor at Universitas Negeri Jakarta. DKI Jakarta 13220, Indonesia coexist in a whole country. The breakdown of harmonious relations has led to various problems in this country. Tribal conflict and community groups still occur frequently, even in the government arena, state leaders who are given the mandate to become an extension of people's tongues, do anarchic things in an argument. Of course, such an attitude becomes inappropriate for the state leaders who should unite to advance and build this nation in reality to overthrow and hate each other. Even recently the mass media reported various crime cases originating from the world of education. Rape, murder, even persecution, and the latest symptoms are now the emergence of bullying and sexual abuse. This fact is made clear by the data held by the "Information and Complaints Data Field of the Indonesian Children Protection Commission (KPAI)" which shows that in 2013 there were 502 complaints from children dealing with the law $(\mathrm{ABH})$ for cases of violence. 187 complaints were made directly, 40 by mail, 34 by telephone and 241 complaints via electronic mail. From January to May 2014, complaints about child sexual violence reached more than 400 complaints (www.kpai.go.id). This fact will certainly have an impact on the country's Defense and Resilience.

The Indonesian Armed Forces (TNI) in this case the Indonesian Navy (TNI AL) in general and Kolinlamil in particular were called upon to provide services to the community in order to instill education in defending the country. Kolinlamil through the Maritime Potential Assistant seeks to conduct state defense education through the Regional Resilience program on State Defense to Kindergarten, Elementary, Middle School, High School / Vocational High School and communities interested in the world of maritime or maritime affairs in North Jakarta and receiving visits to Kolinlamil by schools ranging from kindergarten to university to see the warships owned by Kolinlamil and conduct discussions about Kolinlamil.

Tilman Grammes in his journal entitled Nationalism, Patriotism, Citizenship and Beyond revealed about patriotic education or staatserziehung which is seen as a form of revival of character education, in which in the history of the human world it is no longer Eurocentric. Takahiro Kondo (Nagoya) and Xiaoyan Wu (Japan Society for Promotion of Science) state that patriotism is the goal of education in Chinese and Japanese schools (Tilman Grammes, 2011, Volume 10 Number 1). 
Based on this, the researchers were interested in conducting research on the application of community services in Kolinlamil North Jakarta in the education of defending the country.

\section{LITERATURE REVIEW}

The safety of a nation and state is a condition that must be realized and cannot be negotiated if the nation and state want to survive as a country. To maintain safety, an effort is needed to defend the country. Budiyono (2017: 55-63) explained that defending the country has a very high relation in the current global era in order to strengthen the defense and security of the Indonesian nation amidst the birth of many foreign ideologies that are not in accordance with the identity of the Indonesian nation, with the defense of the state can provide input and new energy to strengthen the character of the Indonesian nation.

Winarno (2013: 182) explained that defending the country is the effort of every citizen of the Republic of Indonesia against threats, both from outside and from within the country. To maintain the stability and security of a country through defense for the state, it is also necessary to pay attention to the interests needed by the country. Dover \& Phythian (2011: 420-444) explains that with national needs or interests it will inevitably force and awaken a citizen to participate in defending his own country based on trust in the values that exist in democracy, law, freedom of speech, tolerance and human rights. In order for education to defend the country to run well, there needs to be a command line or organizational structure to provide good to the needy.

At the individual level, research concentrates on the extent to which employees are service-oriented individuals (Cran, 1994; Hogan, Hogan, \& Busch, 1984; Hurley, 1998; Keillor, Parker, \& Pettijohn, 1999). at the individual level, where it is treated as a measure of personality, to discover the extent of service-oriented people (Homburg et al., 2002). At the organizational level, researchers concentrate on the extent to which all service-oriented companies. Typical elements that contribute to service orientation at the organizational level include corporate culture, human resource management, organizational structure, total supply, and business strategy (D. Bowen, Siehl, \& Schneider, 1989; Homburg et al., 2002, 2003). Service orientation of corporate culture connects the level of individuals and organizations and captures values and behavior in organizations (Calori \& Sarnin, 1991; Deshpand'e \& Webster, 1989; Homburg et al., 2003). By emphasizing values to provide services, companies realize the relevance of service orientation. This behavior describes the extent to which organizational members behave in service-oriented ways and reflect how much value (abstract) the value of services experienced in the organization. The orientation of human resource management services captures the extent to which personnel recruitment, personnel training, and personnel appraisal / compensation consider aspects related to services (D. Bowen et al., 1989; Homburg et al., 2003; Matthyssens \& Vandenbempt, 1998).

What problems contribute to competitive advantage have been seen, in the strategy literature, a shift in emphasis from external positions in industry and the relative balance of competitive forces, towards recognition that internal resources are seen as important for sustained effectiveness (Wright et al., 2001). The work of Penrose (1959) is the beginning of a firm-based view of resources (RBV), then articulated by Rumelt (1984), Barney (1991, 1995) and Dierickx \& Cool (1989). The RBV establishes the importance for organizations to build a valuable set of resources and combine them in a unique and dynamic way to develop the company's success. Competitive advantage does not depend, as traditionally assumed, on a basis such as natural resources, technology, or economies of scale, because it is more easily replicated. Conversely, competitive advantage, according to the RBV, depends on valuable, rare, and difficult to imitate resources within an organization. Human capital in its true sense is terlihat invisible assets '(Itami, 1987). The importance of human resources (a collection of employee capabilities), and how it is managed through the HR process, becomes clear, then, for the organization's strategic goals. In terms of scarcity: ikaIf the type and level of skills are not evenly distributed, so that some companies can get the talent they need and others do not, then (ceteris paribus) the form of human capital can be a source of sustainable competitive advantage '(Snell et al. , 1996: 65). And in terms of not being replicable, there are at least two reasons why human resources might be difficult to imitate: causal ambiguity and road dependence (Becker \& Gerhart, 1996; Barney, 1991). ,First, it is difficult to understand the exact mechanism by which the interaction between practice and human resource policies produces value ... second, this HR system depends on the path. They consist of policies that are developed over time and cannot be easily bought in the market by competitors '(Becker \& Gerhart, 1996: 782). The importance of human resources to play a role in getting a competitive advantage is greater than before because it is important wealth, success and competitive advantage of the organization. "Strategic management of human resources or human capital is a means of gaining competitive advantage through one of the most important assets: the people" (Richard.W 2001). Sources Other sources of competitive advantage, such as technology and physical resources, are relatively easier to replicate and transfer. "To create a workforce that provides a competitive advantage, companies create an environment that provides knowledge, motivation, involvement that will be difficult to imitate by competitors" (Afioni 2007; Agarwal \& Ferret, 2001; Luftman \& kempaiah 2007). Competitors The company's competitors always try to hire better people for the job, so companies must constantly evaluate human factors. Eric D. brown (2007) also concluded that the ability to create unique teams is the most effective way to create sustainable excellencell. The way an organization manages its community can influence its performance (Peter \& Watermann 1982). 
"Employee participation, empowerment and design work, including team-based production systems, extensive employee training and performance contingency incentives are widely believed to improve organizational performance" (Pfeffer 1994). Therefore, an important differentiating factor between companies is how human resources are developed and maintained in certain organizations\| (Yazdani 2008). "The human element has grown important because knowledge has become an important element in gaining competitive advantage, especially in the new economic landscape" (Grant, 1996).

The company's human resource assets are the collective number of attributes, life experiences, knowledge, inventions, energy, and enthusiasm that people choose to invest in their work. Human resources are related to the skills, knowledge, innovation, abilities and competencies of employees as a whole. This represents the goods and services produced by employees who generate income when there is an investment of knowledge, skills and other abilities (Issac, 2009). Choudhury and Mishra (2010) define human capital as individual knowledge, skills and expertise to ultimately make the company work and succeed.

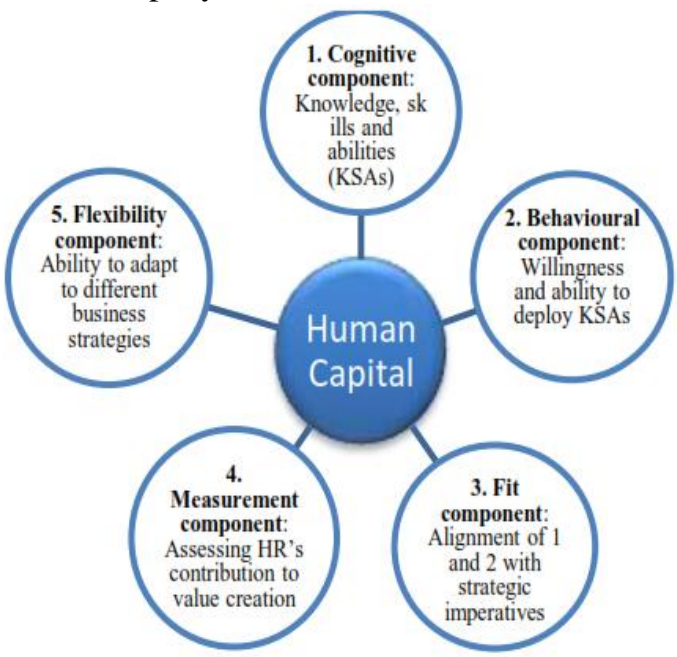

Source: F. Afiouni, (2013)_Human capital management: a new name for HRM?` Int. J. Learning and Intellectual Capital, Vol. 10, No. 1, pp.18-34

\section{METHODOLOGY}

In this study researchers used a research method qualitatively with a case study approach to find out and understand management after organizational change at STMKG, so they could find answers to what happened, why it happened and how it happened as confirmed by Finlay and Ballinger (2006), qualitative is research that can answer why and how an event occurs. In addition, this research is expected to find a management management system after organizational change.

Denzin and Lincoln (2009) explain that qualitative research is brikolase, a series of practices that are integrated and arranged neatly so as to produce solutions to problems in real situations. Qualitative research, according to him, produces a complex, dense, reflective and cliping creation that represents the image, understanding, and interpretation of researchers about the world or phenomena being analyzed. This shows that qualitative research is basically understanding and interpreting what happens to individuals in a society or other objects. Creswell (2010) adds that in qualitative research involves important activities, such as asking questions and research procedures, collecting specific data from participants, analyzing data in depth, and conducting investigations subjectively. The researcher took a qualitative method with a case study approach (Haines, 2000).

\section{RESULTS \& DISCUSSION}

Kolinlamil North Jakarta organizational structure

The Staff of Maritime Potential for the CO of Sea Lift Command (Spotmar Pangkolinlamil), led by the Assistant Maritime Potential, abbreviated as Aspotmar Pangkolinlamil, as the implementing element, is directly located and responsible to the Pangkolinlamil. The hope is that the Maritime Potential Service (Dispotmar) Kolinlamil can be formed as an element of implementing the maritime potential development center at the Kolinlamil level which should be there.

\section{A. Leadership Element. Head of the Kolinlamil Maritime Potential Development Service, abbreviated as Kadispotmar Kolinlamil.}

1. Implementing Elements

The Head of the Sub Division of Ability Division is abbreviated as Kasubdis Binpuan, who oversees:

a) Officers of Guidance / Maritime Affairs Planning Affairs are abbreviated as Paur Renbin / Masymar.

b) The Executing Officer for Education and Training Affairs is abbreviated as Paur Diklat

2. The Head of Subdistrict for the Development of Regional and Border Areas Resilience is abbreviated as Kasubdis Bintahwiltas in charge of: Officer of Regional and Border Resilience Affairs abbreviated as Paur Bintahwiltas.

3. Head of Sub-Department of Social Communication \& Service Division of TIN AL, abbreviated as Head of Sub-Division of Social Affairs and Community Service of the Indonesian Navy supervising:

a) Officer in the field of Social Communication Affairs abbreviated as Paur Komsos.

b) The Indonesian Navy's Service Affairs Officer is abbreviated as the Indonesian Navy's Paur Bakti.

4. The Head of the National Ocean Transportation Sector Sub-Department of Transportation, abbreviated as Kasubdis Anglanas, is in charge:

a) Officer for Injasmar Affairs Affairs abbreviated as Injurmar Paur.

b) The National Marine Transport Affairs Officer is abbreviated as Paur Anglanas.

5. Service Elements. Head of Administration and Internal Affairs abbreviated as Ka Taud.

a) Spotmar Satlinlamil. Spotmar Kolinlamil was led by Aspotmar And Satlinlamil as the supporting elements of 
the leadership who were directly located and responsible to the Pangkolinlamil. In addition, the Spotmar Kolinlamil should have the authority of Dispotmar Satlinlamil as the implementing element of the maritime potential development center at the level linlamil.

\section{1) Assistant Leadership Elements}

The Assistant Officer for Planning, Potmar's ability is abbreviated as Paban Renpuan, who oversees:

1. Middle Assistant Officer for Planning and Budget is abbreviated as Pabandya Ren Gar.

2. Associate Assistant Officer for Potential Ability Planning, abbreviated as Pabandya Renpotmar

a) Assistant Officers for Border Area and Regional Resilience Development abbreviated as Paban Bintahwil and Wiltas supervise: Middle Assistant Officers for Regional Resilience abbreviated as Pabandya Bintahwil Tas.

b) The Assistant Staff of the Social Communication and Service Division of the Indonesian Navy was abbreviated as Paban Komsos and Bakti TNI AL who supervised:

a) Middle Assistant Officer for Social Communication, abbreviated as Pabandya Komsos.

b) Intermediary Assistant Field Officer for the Indonesian Navy is abbreviated as Pabandya Bakti TNI AL.

c) The National Marine Transport Assistant Officer is abbreviated as Paban Anglanas who oversees:

a) Associate Assistant Officer for Maritime Services Industry abbreviated as Pabandya Injasmar.

a) The Associate Assistant of the National Sea d)Transport Sector, abbreviated as Pabandya Anglanas.Service Elements. Head of Administration and Internal Affairs abbreviated as Ka Taud.

1. Kolinlamil North Jakarta organization culture in providing community services

In Law No. 34 of 2004 concerning the TNI, it is stated that TNI identity is the people's soldier, combatant soldier, national soldier and professional soldier, then the prevailing culture in the TNI organization is a culture based on the identity of the people's soldier, combatant soldier, national soldier, professional soldier.

The culture is applicatively described in doctrines, and the code of ethics / code of honor that must be followed, upheld and carried out by every TNI soldier in his life.

As one of the TNI's organizational units, the core values in the culture of the TNI organization described above are also the core values of organizational culture that apply to the Navy. The organizational culture of the Navy is a sub culture of the culture of the TNI organization, because the Navy has a series of additional values in its organizational culture, but overall it still adheres to the core values or core values of the
TNI organization as the core of organizational culture. The existence of additional cultural values required by the Navy itself with regard to the nature, role, duties and functions of intimacy. In general the typical culture of the Navy is formed through the basic education (Dikma) at the stage of "Group Basic Education (Diksargol)", which was carried out after the basic education stage of the craftsmen (Diksarrit).

As soldiers of the sea, besides having an identity as a Pancasila soldier and Sapta Margais, they also have a code of ethics as stated in the Tri Sila of the Navy, namely; discipline, hierarchy, and honor of soldiers. The three precepts of the Tri Sila were taught, instilled and cultivated into every Navy soldier considering the demands of the maritime service which were full of challenges.

To help achieve high operational preparedness in the entire ranks of the Navy, the creation of discipline and order both on the KRI and in the Navy's Landing, as well as maintaining the unique and universal traditions and values of the Navy, the Navy composes the rules -regulations of its implementation in the book "Special Navy Service Regulations", to serve as a guide for all members of the Navy.

\section{Capital Owned By Kolinlamil In Providing Services To The Public}

Kolinlamil to provide services to the community well, the leader gave assignments to the Office of Information and Assistant Potential Martim (Aspotmar) with the rank of Junior Officer starting from Lieutenant to Captain. The placement of these officers will be able to provide correct information to the public about the history of the ships visited, the history of the former World War II era, the state's defense education in the form of Bintal Juang Remaja Bahari for junior high school students to universities and the general public. These activities are expected to occur knowledge sharing to the students about Kolinlamil, the importance of national defense and maritime.

\section{CONCLUSION}

The need for the establishment of the Maritime Potential Service is in charge of several assistants so that they have more extensive authority compared to the Maritime Potential Assistance, 2) a strong organizational culture in the form of discipline, hierarchy, and military honor is the basis for Navy officers in carrying out their duties including providing services to community so that the values of discipline in Nurturing (Pembinaan) activities, Mentality (Mental) Juang Remaja Bahari are things that cannot be forgotten by the participants, and 3) There needs to be an SOP as a standard for officers tasked with providing services about the ins and outs of ships owned by Kolinlamil so that things that cannot be informed are known by officers.

\section{REFERENCES}

[1] Afiouni, F. (2009) =Leveraging human capital and value creation by combining HRM and KM initiatives', International Journal of Learning and Intellectual Capital, Vol. 6, No. 3, pp.202-213

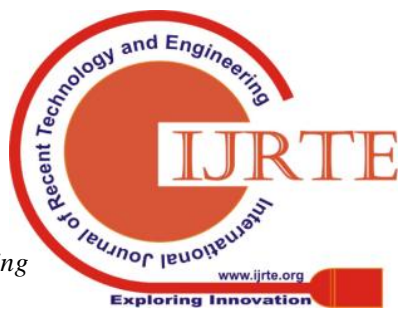


[2] Agarwal, R. and T. Ferret, 2001. "Crafting an HR strategy to meet the need for It workers". Association for computing Machinery. Communications of the ACM, 44(7): 58 .

[3] Barney, J. (1991)_Firm resources and sustained competitive advantage“, Journal of Management, Vol. 17, No. 1, pp.99-120.

[4] Barney, J. (1991). "Firm resources and sustained competitive advantage", Journal of Management, Vol. 17, No. 1, pp.99-120

[5] Becker \& Gerhart, (1996). "The impact of human resource management on organizational performance: Progress and prospects". Academy of

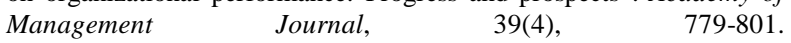
http://dx.doi.org/10.2307/256712

[6] Bowen, D.E., Siehl, C., \& Schneider, B. (1989). "A framework for analyzing customer serviceorientation in manufacturing". Academy of Management Review, 14,75-95.

[7] Budiyono. 2017. Memperkokoh idiologi negara pancasila melalui bela negara. Citizenship Jurnal Pendidikan Pancasila dan Kewarganegaraan. 5(1) 55-63.

[8] Calori, R. \& Sarnin, P. (1991). "Corporate Culture and Economic Performance: A French Study", Organization Studies, 12(1): 49-74

[9] Choudhury dan Mishra (2010). Theoretical and Empirical Investigation of Impact of Developmental HR Configuration on Human Capital Management, International Business Research, Vol. 3, No. 4. October, pp. $181-186$

[10] Deshpand'e \& Webster, (1989). Organizational culture and marketing Defining the research agenda. Journal of Marketing, 53, 3-15

[11] Dierickx \& Cool (1989). "Asset Stock Accumulation and Sustainability of Competitive Advantage", Management Science Vol. 35, No. 12, December 1989, Primed in U.S.A.

[12] Dover, R., \& Phythian, M. 2011. Lost over Libya: the 2010 strategic defence and security review - an obituary. Journal Defence Studies, 11(3), 420-444. https://doi.org/10.1080/14702436.2011.630175

[13] Grant, R.M., (1996). "Toward a knowledge-based theory of the firm.' Strategic Management Journal, 17(Special Issue): 109-122

[14] Hogan, J., Hogan, R., \& Busch, C. M. (1984). "How to measure service orientation". Journal of Applied Psychology, 69(1), 167-173. http://dx.doi.org/10.1037/0021-9010.69.1.167

[15] Homburg et al., 2002. "Fundamental Changes in Marketing Organization: The Movement Towards a Customer-Focused Organizational Structure." Journal of the Academy of Marketing Science 28 (4): 459-79.

[16] Hurley, S. L. (1998), Consciousness in Action. Cambridge: Harvard University Press.

[17] Itami, H. (1987). Mobilising Invisible Assets. Boston: HBS Press

[18] Keillor, Parker, \& Pettijohn, 1999. Sales Force Performance Satisfaction and Aspects of Relational Selling: Implications for Sales Manager's, Journal of Marketing Theory and Practice Winter, 63(1); pp. 101-14

[19] Luftman, J. and R.M. Kempaiah, (2007). "The Is Organisation of the future: The It Talent Challenge". Information System Management, 24 (2): 129

[20] Matthyssens \& Vandenbempt, (1998). Critical role and screening practices of European business incubators, Journal of Business \& Industrial Marketing, 13 (4/5), 339-355

[21] Peter, T. and Jr. Waterman, (1982). In search of Excellence. New York: Harper and Row

[22] Pfeffer, J., 1994. Competitive Advantage through People. Boston: Harvard School Business Press

[23] Richard.W (2001). "He Return on Human Capital”. Journal of Business Strategy, July - August

[24] Sihar Simanullang, BUDAYA ORGANISASI DAN PENDIDIKAN (Studi Budaya Militer dan Budaya Akademik di Akademi TNI Angkatan Laut Surabaya), http://jurnal.untag-sby.ac.id/index.php/jpap/article/download/712/641

[25] Snell et al., (1996). "Human Resources Strategy: The Era of Our Ways (CAHRS Working Paper \#00-17)". Ithaca, NY: Cornell University, School of Industrial and Labor Relations, Center for Advanced Human Resource Studies. http://digitalcommons.ilr.cornell.edu/cahrswp/95

[26] Takahiro Kondo dan Xiaoyan Wu (2011). A comparative study of "patriotism" as a goal of school education in China and Japan Vergleichende Analyse des "Patriotismus" als Erziehungsziel in China und Japan", Journal of Social Science Education, Volume 10, Number 1,2011 , pp. 23-32

[27] Tilman Grammes, "Nationalism, Patriotism, Citizenship and Beyond", Journal of Social Science Education, Volume 10, Number 1, 2011, pp. $2-11$

[28] Winarno. 2013. Paragdigma baru pendidikan kewarganegaraan (panduan kuliah di perguruan tinggi). Jakarta: PT Bumi Aksara.

[29] Wright, P.M., McMahan, G.C. and McWilliams, A (1994). "Human resources and sustained competitive advantage: a resource-based perspective". International Journal of Human Resource Management, Vol. 5, No. 2, p. 301-326
[30] Yazdani, N., 2008. "Assesing the Link Between Intellectual Capita formation and Performance of a University". South Asian Journal of Management Sciences, 2(1): 206-230.

\section{AUTHORS PROFILE}

I am Ceppi Hilmansyah from the Department of Management (MSDM) Post Graduated Universitas Negeri Jakarta. DKI Jakarta 13220, Indonesia. My area of interest is accounting and fiance.

My name is Prof.Dr.Ma'ruf, Prof and currently working as Profesor at Universitas Negeri Jakarta. DKI Jakarta 13220, Indonesia. My area of interest is social issues and poitics.

Dr.Suparno Eko Widodo M.M working as Profesor at Universitas Negeri Jakarta. DKI Jakarta 13220, Indonesia. My area of interest is eduation and political science. 